\title{
Testing intravitreal toxicity of rapamycin in rabbit eyes
}

\author{
Toxicidade intravítrea da rapamicina em olhos de coelhos
}

\author{
Roberta Pereira de Almeida Manzano ${ }^{1}$ \\ Gholam A. Peyman² \\ Palwasha Khan ${ }^{3}$ \\ Muhamet Kivilcim ${ }^{4}$ \\ Patricia Chevez-Barrios ${ }^{5}$ \\ Walter Takahashi $^{6}$
}

\begin{tabular}{|l|}
\hline ABSTRACT \\
\hline Purpose: To evaluate retinal toxicity of varying doses of rapamycin when \\
injected intravitreally in rabbits. Rapamycin is a potent immunosup- \\
pressive agent with significant antitumor and antiangiogenic properties, \\
clinically approved for prevention of organ transplant rejection. Methods: \\
Twelve New Zealand albino rabbits were divided into four groups. Four \\
different doses of rapamycin were prepared in 0.1 ml: $20 \mu g, 50 \mu g, 200 \mu g$, \\
and $1000 \mu$ g. Each concentration was injected in one eye of three rabbits, \\
and 0.1 ml volume of sterile BSS was injected into the contralateral eye of \\
the three rabbits. Slit-lamp and fundoscopic examinations were perfor- \\
med and the animals were observed for 2 weeks for signs of infection, \\
inflammation, and toxicity. A baseline ERG was performed before drug \\
treatment and at day 14, after which the rabbits were euthanized. Histology \\
of the enucleated eyes was studied to look for retinal toxicity. Results: \\
ERG results showed some decrease in scotopic response; however this \\
was not dose related. ERG results were normal at $20 \mu$ g. Histological \\
results showed no retinal toxicity in all groups. Conclusion: Although \\
ERG changes were identified at dosages between $50-1000 \mu g$, the histology \\
of all groups up to $1000 \mu g$ did not show any discernable abnormalities.
\end{tabular}

Keywords: Choroidal neovascularization; Sirolimus/toxicity; Uveitis; Vascular endothelial growth factor receptor-1; Rabbits

\footnotetext{
Trabalho realizado na Tulane University - New Orleans - USA.

${ }^{1}$ MD, Department of Ophthalmology, Universidade de São Paulo - USP - São Paulo (SP) - Brazil. MD, Department of Ophthalmology, Santa Casa de Misericórdia de São Paulo - São Paulo (SP) - Brazil.

${ }^{2} \mathrm{MD}$, Department of Ophthalmology, University of Arizona - Tucson - EUA.

${ }^{3} \mathrm{MD}$, Department of Ophthalmology, Tulane University, New Orleans - EUA.

${ }^{4} \mathrm{MD}$, Department of Ophthalmology, Tulane University, New Orleans. MD, Department of Ophthalmology, University of Arizona - Tucson - EUA.

${ }^{5}$ MD, Department of Pathology, The Methodist Hospital - Houston - EUA.

${ }^{6} \mathrm{MD}$, Department of Ophthalmology, Universidade de São Paulo - USP - São Paulo (SP) - Brazil.

Corresponding author: Roberta P. A. Manzano. Rua Aramanaí, 307 - São Paulo (SP) CEP 05450-030

E-mail: roberta.manzano@gmail.com

None of the authors has any proprietary interest in any technique or product described herein.

Recebido para publicação em 12.03.2008

Aprovação em 25.11.2008
}

\section{INTRODUCTION}

Treatment of severe ocular inflammation may require long-term use of immunosuppressive drugs. Long-term use of these drugs is problematic because of their adverse side effects. To decrease these adverse side effects, intravitreal administration is a possible treatment option.

Rapamycin (sirolimus; A.G. Scientific, San Diego, CA) is a cyclic macrolide antibiotic isolated from the fungus Streptomyces hygroscopicus ${ }^{(1)}$. It is a potent immunosuppressive agent, clinically approved for prevention of organ transplant rejection ${ }^{(2)}$. It has been used in sirolimus eluting stents in patients with coronary artery disease ${ }^{(3)}$, as it also has antiproliferative effects on smooth muscle cells and on arterial intimal thickening ${ }^{(4)}$. Similar to cyclosporine and tacrolimus, it is an inhibitor of $\mathrm{T}$ cell activation. However, it has no effect on the calcineurin/calmodulin complex and binds to intracellular receptors known as immunophilins. Rapamycin inhibits two protein kinases-termed the mammalian target of rapamycin (mTOR 1 and mTOR 2) - associated with cell cycle progression in the G1 phase. Rapamycin interferes with cell cycle progression in a later stage than cyclosporin and FK 506, blocking not the proliferation-stimulating factors but the proliferation signal that is induced by these factors ${ }^{(5)}$. 
Rapamycin has significant antitumor and antiangiogenic activities. Several rapamycin-related compounds are in phase I, II and III clinical trials in patients with renal cancer and other malignancies ${ }^{(6)}$. In an in vivo experiment with rats, rapamycin dramatically inhibited tumor growth, with a marked decrease in tumor vascularization ${ }^{(7)}$. Guba et al. demonstrated the antiVEGF activity of sirolimus in a murine tumor model ${ }^{(8)}$. Its antiangiogenic properties were also demonstrated in a 1995 study by Olsen et al. who showed that rats receiving sirolimus following orthotopic allogenic corneal grafts had reduced amounts of corneal neovascularization ${ }^{(9)}$. Recently, it was demonstrated that rapamycin significantly reduced the extent of neovascularization in both experimental choroidal neovascularization $(\mathrm{CNV})$ and retinopathy of prematurity (ROP) in mice $^{(10)}$.

Rapamycin has been shown to reduce inflammation in animal models of experimental autoimmune uveitis, in combination with tacrolimus and cyclosporine ${ }^{(11-12)}$. Recent investigation has revealed that rapamycin is an effective and potent immunosuppressive treatment for patients with non-infectious uveitis and can reduce the need for long-term supplementary corticosteroid therapy ${ }^{(13)}$.

One possible option of treatment for chronic non-infectious uveitis, choroidal, or retinal neovascularization could be an intravitreal injection of rapamycin based on its immunosuppressive and antiangiogenic properties. However, retinal toxicity is a primary concern when using intravitreal injections. The purpose of our study was to analyze the retinal toxicity of rapamycin at various doses.

\section{METHODS}

\section{Animals}

Twelve New Zealand albino rabbits weighing between 2 and $3 \mathrm{~kg}$ were used for this study. The rabbits were treated according to guidelines of the Association for Research in Vision and Ophthalmology (ARVO). Slit-lamp and indirect fundoscopic examinations were performed on all eyes prior to the study and on days 1, 7, and 14 after intravitreal injection. Any rabbit that demonstrated corneal or lens opacity or retinal damage prior to the study was excluded. Rabbits were anesthetized before all procedures using approximately $1 \mathrm{ml}$ of a mixture of ketamine hydrochloride $(50 \mathrm{mg} / \mathrm{kg}$ ) and xylazine hydrochloride $(5 \mathrm{mg} / \mathrm{kg})$. The eyes were dilated by topical application of phenylephrine (2.5\%) and tropicamide $(0.5 \%)$. Topical anesthesia was applied using proparacaine $(0.5 \%)$.

\section{Intravitreal injections}

All procedures were performed under sterile conditions using an operating microscope for visualization. Anterior chamber tap was performed with a $25 \mathrm{G}$ needle withdrawing $0.1 \mathrm{cc}$ of aqueous fluid to reduce intraocular pressure and to minimize drug reflux following injection. Intravitreal injection was performed using a $30 \mathrm{G}$ needle attached to a tuberculin syringe inserted bevel up approximately $2 \mathrm{~mm}$ posterior to the limbus. Four different doses of rapamycin were prepared in $0.1 \mathrm{ml}: 20 \mu \mathrm{g}$, $50 \mu \mathrm{g}, 200 \mu \mathrm{g}$, and $1000 \mu \mathrm{g}$. Each dose was injected in one eye of three rabbits, and $0.1 \mathrm{ml}$ volume of sterile BSS was injected into the contralateral eye of the three rabbits. Slit-lamp and fundoscopic examinations were performed and the animals were observed for 2 weeks for signs of infection, inflammation, and toxicity.

\section{Electrophysiological tests}

ERG using the UTAS-2000 system (LKC Technology, Gaithersburg, MD) was performed prior to and 14 days after intravitreal injection. Rabbits were dark-adapted for at least 30 minutes after pupillary dilation. Unipolar contact lenses (ERG jet electrodes) were put on both corneas with Goniosol (IOLab Corporation, Claremont, CA); the negative electrode was placed in the subcutaneous space of the forehead, and the ground electrode was clipped to the earlobe with some electric gel. The dark-adapted scotopic response (step 1, Rod response), scotopic flash response (step 2, Maximal response, cone+ rod) and (after waiting 3 minutes) light-adapted photopic response (step 4, Cone response) were recorded. The average of five sweeps was determined for each step. The difference between $\mathbf{a}$ and $\mathbf{b}$ waves was calculated for each step. The baseline was compared to the response 2 weeks after injection.

\section{Histological examination}

Following the final ERG session, all rabbits were euthanized with an intravenous injection of sodium pentobarbital. The eyes were enucleated and fixed in Karnovsky fixative for 48 hours and then processed, sectioned, and stained with hematoxylin and eosin for light microscopy.

\section{RESULTS}

\section{Clinical examination}

No corneal opacity, cataract, vitreous hemorrhage, retinal detachment, or optic atrophy was seen in any of the rabbit eyes by fundoscopic examination.

\section{Electrophysiological tests}

Follow-up ERGs showed some decrease in 2 of 3 eyes varying in the amplitude of the following groups: $50 \mu \mathrm{g}, 200 \mu \mathrm{g}$, and $1000 \mu \mathrm{g}$. However, this decrease was not dose related and was never extinguished (Figures 1,2).

\section{Histological examination}

Histological examination of the eyes and retinas showed no toxic damage; in particular there was no necrosis, gliosis, degeneration of photoreceptors or neurons, retinal detachment, or inflammation in any of the eyes examined at any dosage (Figures 3, 4). 


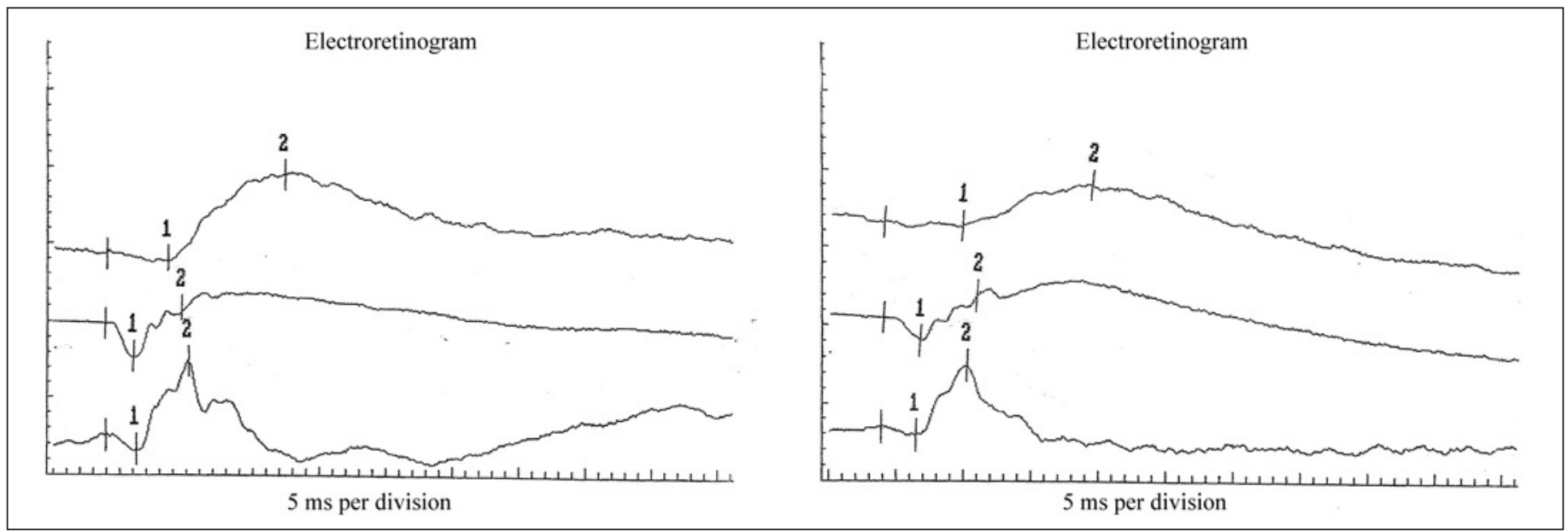

Figure 1 - ERG step 1, 2, and 4 of one rabbit eye before (left) and 14 days after (right) intravitreal injection of $200 \mu \mathrm{g}$ rapamycin. There is a decrease in the amplitude of step 1.

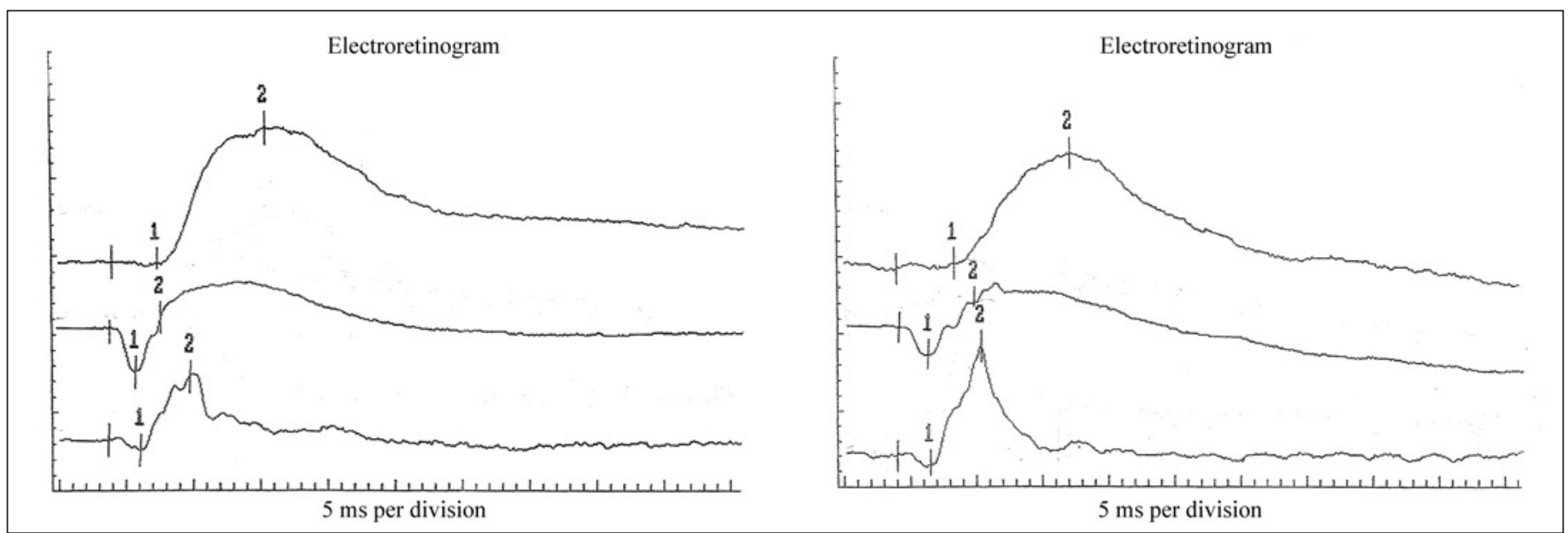

Figure 2 - ERG step 1, 2, and 4 of one rabbit eye before (left) and 14 days after (right) intravitreal injection of $1000 \mu \mathrm{g}$ rapamycin. There is a nonsignificant decrease in step 1 and 2, and an increase in amplitude in step 4.

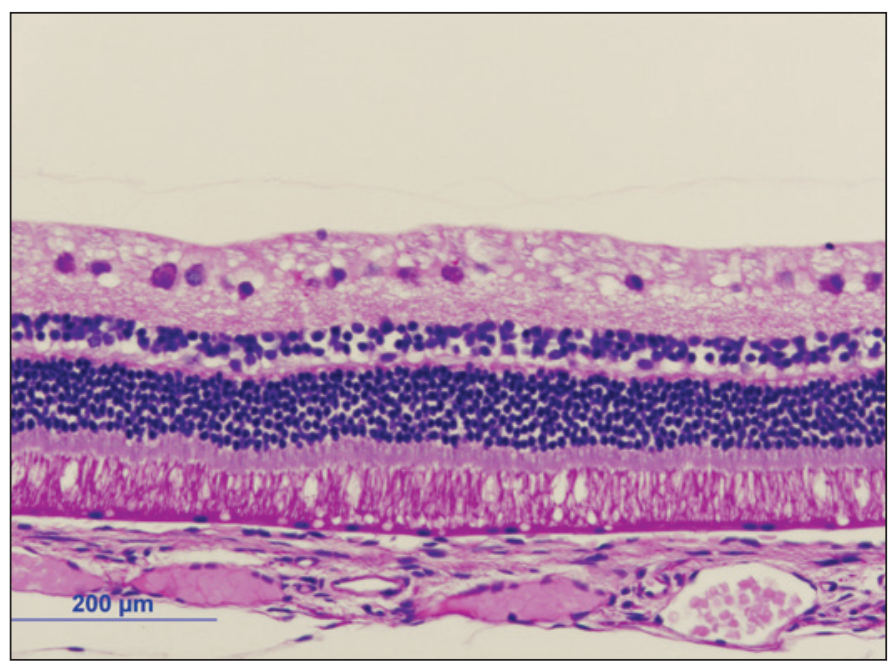

Figure 3 - Normal retinal histology in rabbit eye after intravitreal injection of $200 \mu \mathrm{g}$ rapamycin (H\&E stain)

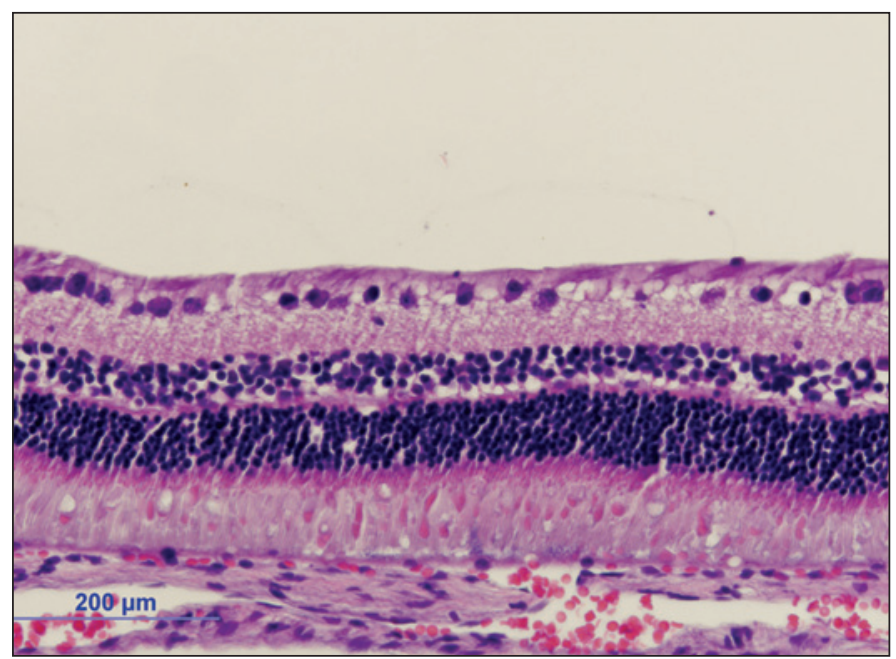

Figure 4 - Normal retinal histology in rabbit eye after intravitreal injection of $1000 \mu \mathrm{g}$ rapamycin (H\&E stain) 


\section{DISCUSSION}

Rapamycin appeared to be non-toxic to the retina in albino rabbits; however, we observed some decrease in ERG amplitude, mainly in the scotopic response in a few eyes. The ERG findings were not uniform in each group nor were they dose related. We think this finding might have been related to reduced body temperature occurring in a cold room in anesthetized animals during dark adaptation ${ }^{(14-15)}$. Hypothermia decreases general body metabolism, leading to a reduction in the rate of chemical reactions and the amplitude of the ERG in mice and rabbits ${ }^{(14-15)}$.

Another possibility for this slight decrease in the a-wave amplitude is that rapamycin (a lipophilic compound) might be localized in the region of photoreceptor or a pigment epithelium, thus creating some dysfunction of the photoreceptor. Further studies including immunohistochemical assays of drug localization should be done to confirm this possibility.

Maybe the histology is not sensitive enough since doses below $50 \mu \mathrm{g}$ did not cause any ERG changes. We can have some functional damage without any change in the histology. Nevertheless, normal ERG does not rule out functional and possible structural changes at the level of ganglion cells or the nerve fiber layer. The lack of changes by light microscopy does not exclude possible alterations at a submicroscopic level. Further studies must be done to evaluate this possibility.

An important characteristic of rapamycin is its antiangiogenic property.

Numerous clinical and experimental observations have indicated that ischemia or hypoxia triggers retinal neovascularization through an excessive production of angiogenic factors. Among multiple factors, many investigators have reported vascular endothelial growth factor (VEGF) to be an important ${ }^{(16-17)}$ and major stimulus responsible for neovascularization in exudative age-related macular degeneration (ARMD) ${ }^{(18)}$.

Intravitreal injections of VEGF inhibitors such as pegaptanib $^{(19-20)}$, ranibizumab ${ }^{(21-22)}$, and bevacizumab ${ }^{(23)}$ have been commonly used to treat CNV.

Intravitreal injection of rapamycin may have a potential in the treatment of CNV in ARMD. The antiangiogenic properties of rapamycin are associated with a decrease in VEGF production and a reduction in the response of vascular endothelial cells to stimulation by $\operatorname{VEGF}^{(8)}$. The mechanism by which rapamycin elicits its effects is not clear. mTOR is an upstream activator of hypoxia inducible factor $1 \alpha(\mathrm{HIF}-1 \alpha)$, a transcription factor that mediates the transcriptional regulation of $\mathrm{VEGF}^{(24-25)}$. In hypoxic cells, rapamycin can interfere with HIF- $1 \alpha$ activation by increasing the rate of its degrada$\operatorname{tion}^{(24)}$.

Other proangiogenic agents such as basic fibroblast growth factor (bFGF), platelet derived growth factor B (PDGF-B), nitric oxide synthase, and angiopoietin are upregulated by hypo$\mathrm{xia}^{(26)}$. Hypoxia can stimulate gene expression by different me- chanisms including gene transcription, regulation at the translational level, and mRNA stabilization. Rapamycin affects mTOR, thereby influencing all these pathways ${ }^{(5,27)}$. Therefore, rapamycin may also be exerting its effects through additional nonVEGF related pathways.

Our study showed that rapamycin did not cause any histologic changes to the rabbit retina when injected intravitreally up to a concentration of $1000 \mu \mathrm{g}$. Further studies are warranted to evaluate the long-term safety of high doses of this drug. Intravitreal rapamycin may offer another option for the treatment of CNV in ARMD, retinal neovascularization, and chronic uveitis.

\section{RESUMO}

Objetivo: Avaliar a toxicidade da injeção intravítrea de diferentes doses de rapamicina para a retina de coelhos. Rapamicina é uma potente droga imunossupressora aprovada clinicamente para a prevenção da rejeição de transplantes de orgãos. Métodos: Doze coelhos albinos da Nova Zelândia foram usados neste estudo. Foram divididos em quatro grupos. Quatro diferentes doses de rapamicina foram preparadas nas seguintes concentrações: $20 \mu \mathrm{g}, 50 \mu \mathrm{g}, 200 \mu \mathrm{g}, 1000 \mu \mathrm{g}$. Foram realizadas injeções intravítreas de $0,1 \mathrm{ml}$ de cada concentração em um olho de três coelhos e $0,1 \mathrm{ml}$ de solução salina foi injetada no olho contralateral de cada coelho. Foram realizadas biomicroscopia e fundoscopia e observamos sinais de inflamação, infecção ou toxicidade durante duas semanas. Fizemos um ERG antes do tratamento e outro 14 dias depois da injeção intravítrea. Os animais foram sacrificados, fizemos a enucleação dos olhos e preparamos o tecido para a avaliação histológica. Resultados: Os resultados do ERG e da histologia demonstraram diminuição da resposta escotópica, entretanto essa diminuição não foi dose dependente. A histologia foi normal em todos os grupos. Conclusão: A injeção intravítrea de rapamicina levou a alterações eletrorretinográficas nos grupos de 50-1000 $\mu \mathrm{g}$, entretanto a histologia foi normal em todos os grupos até $1000 \mu \mathrm{g}$.

Descritores: Neovascularização coroidal; Sirolimo/toxicidade; Uveite; Receptor 1 do fator de crescimento do endotélio vascular; Coelhos

\section{REFERENCES}

1. Sehgal SN, Baker H, Vézina C. Rapamycin (AY-22,989), a new antifungal antibiotic. II. Fermentation, isolation and characterization. J Antibiot (Tokyo). 1975;28(10):727-32.

2. Dupont P, Warrens AN. The evolving role of sirolimus in renal transplantation. QJM. 2003;96(6):401-9.

3. Moses JW, Leon MB, Popma JJ, Fitzgerald PJ, Holmes DR, O'Shaughnessy C, Caputo RP, Kereiakes DJ, Williams DO, Teirstein PS, Jaeger JL, Kuntz RE; SIRIUS Investigators. Sirolimus-eluting stents versus standard stents in patients with stenosis in a native coronary artery. N Engl J Med. 2003; 349(14):1315-23. Comment in: N Engl J Med. 2003;349(14):1307-9. N Engl J Med. 2004;350(4):413-4; author reply 413-4. N Engl J Med. 2004;350(4): 413-4; author reply 413-4. 
4. Gregory CR, Huie P, Billingham ME, Morris LE. Rapamycin inhibits arterial intimal thickening caused by both alloimmune and mechanical injury. Its effect on cellular, growth factor, and cytokine response in injured vessels. Transplantation. 1993;55(6):1409-18.

5. Sehgal SN. Rapamune (RAPA, rapamycin, sirolimus): mechanism of action immunosuppressive effect results from blockade of signal transduction and inhibition of cell cycle progression. Clin Biochem. 1998;31(5):335-40. Republished in: Clin Biochem. 2006;39(5):484-9.

6. Bjornsti MA, Houghton PJ. The TOR pathway: a target for cancer therapy. Nat Rev Cancer. 2004;4(5):335-48.

7. Liu M, Howes A, Lesperance J, Stallcup WB, Hauser CA, Kadoya K, et al. Antitumor activity of rapamycin in a transgenic mouse model of ErbB2dependent human breast cancer. Cancer Res. 2005;65(12):5325-36.

8. Guba M, von Breitenbuch P, Steinbauer M, Koehl G, Flegel S, Hornung M, et al. Rapamycin inhibits primary and metastatic tumor growth by antiangiogenesis: involvement of vascular endothelial growth factor. Nat Med. 2002 8(2):128-35. Comment in: Kidney Int. 2003;63(3):1160-1.

9. Olsen TW, Benegas NM, Joplin AC, Evangelista T, Mindrup EA, Holland EJ. Rapamycin inhibits corneal allograft rejection and neovascularization. Arch Ophthalmol. 1994;112(11):1471-5. Erratum in: Arch Ophthalmol 1995; 113(2): 144

10. Dejneka NS, Kuroki AM, Fosnot J, Tang W, Tolentino MJ, Bennett J. Systemic rapamycin inhibits retinal and choroidal neovascularization in mice Mol Vis. 2004;10:964-72.

11. Ikeda E, Hikita N, Eto K, Moshisuki M. Tacrolimus-rapamycin combination therapy for experimental autoimmune uveoretinitis. Jpn J Ophthalmol. 1997; 41(6):396-402.

12. Martin DF, DeBarge LR, Nussenblatt RB, Chan CC, Roberge FG. Synergistic effect of rapamycin and cyclosporin $\mathrm{A}$ in the treatment of experimental autoimmune uveoretinitis. J Immunol. 1995;154(2):922-7.

13. Shanmuganathan VA, Casely EM, Raj D, Powell RJ, Joseph A, Amoaku WM, Dua HS. The efficacy of sirolimus in the treatment of patients with refractory uveitis. Br J Ophthalmol. 2005;89(6):666-9.

14. Mizota A, Adachi-Usami E. Effect of body temperature on electroretinogram of mice. Invest Ophthalmol Vis Sci. 2002;43(12):3754-7.

15. Lachapelle P, Benoit J, Guité P. The effect of in vivo retinal cooling on the electroretinogram of the rabbit. Vision Res. 1996;36(3):339-44.

16. Ferrara N. VEGF and the quest for tumour angiogenesis factors. Nat Rev Cancer. 2002;2(10):795-803

17. Leung DW, Cachianes G, Kuang WJ, Goeddel DV, Ferrara N. Vascular endothelial growth factor is a secreted angiogenic mitogen. Science. 1989; 246(4935):1306-9.

18. Kvanta A, Algvere PV, Berglin L, Seregard S. Subfoveal fibrovascular membranes in age-related macular degeneration express vascular endothelial growth factor. Invest Ophthalmol Vis Sci. 1996;37(9):1929-34.

19. Gragoudas ES, Adamis AP, Cunningham ET Jr, Feinsod M, Guyer DR; VEGF Inhibition Study in Ocular Neovascularization Clinical Trial Group. Pegaptanib for neovascular age-related macular degeneration. N Engl J Med. 2004;351(27):2805-16. Comment in: ACP J Club. 2005;143(1):18. N Engl J Med. 2004;351(27):2863-5. N Engl J Med. 2005;352(16):1720-1; author reply $1720-1$.

20. VEGF Inhibition Study in Ocular Neovascularization (V.I.S.I.O.N.) Clinical Trial Group, D'Amico DJ, Masonson HN, Patel M, Adamis AP, Cunningham ET Jr, Guyer DR, Katz B. Pegaptanib sodium for neovascular age-related macular degeneration: two-year safety results of the two prospective, multicenter, controlled clinical trials. Opthalmology. 2006;113(6): 992-1001.e6.

21. Michels S, Rosenfeld PJ. Ranibizumab therapy for neovascular age related macular degeneration. Retinal Physician. 2004;1(1):16-22.

22. Rosenfeld PJ, Heier JS, Hantsbarger G, Shams N. Tolerability and efficacy of multiple escalating doses of ranibizumab (Lucentis) for neovascular age-related macular degeneration. Ophthalmology. 2006;113(4):623.e1.

23. Avery RL, Pieramici DJ, Rabena MD, Castellarin AA, Nasir MA, Giust MJ. Intravitreal bevacizumab (Avastin) for neovascular age-related macular degeneration. Ophthalmology. 2006;113(3):363-72.e5.

24. Hudson CC, Liu M, Chiang GG, Otterness DM, Loomis DC, Kaper F, et al. Regulation of hypoxia-inducible factor 1alpha expression and function by the mammalian target of rapamycin. Mol Cell Biol. 2002;22(20):7004-14.

25. Gerber HP, Condorelli F, Park J, Ferrara N. Differential transcriptional regulation of the two vascular endothelial growth factor receptor genes. Flt1, but not Flk-1/KDR, is up-regulated by hypoxia. J Biol Chem. 1997;272(38): 23659-67.

26. Humar R, Kiefer FN, Berns H, Resink TJ, Battegay EJ. Hypoxia enhances vascular cell proliferation and angiogenesis in vitro via rapamycin (mTOR)dependent signaling. FASEB J. 2002;16(8):771-80. Erratum in: FASEB J. 2006;20(9):1573.

27. Treins C, Giorgetti-Peraldi S, Murdaca J, Semenza GL, Van Obberghen E. Insulin stimulates hypoxia-inducible factor 1 through a phosphatidylinositol 3-kinase/target of rapamycin-dependent signaling pathway. J Biol Chem. 2002;277(31):27975-81.

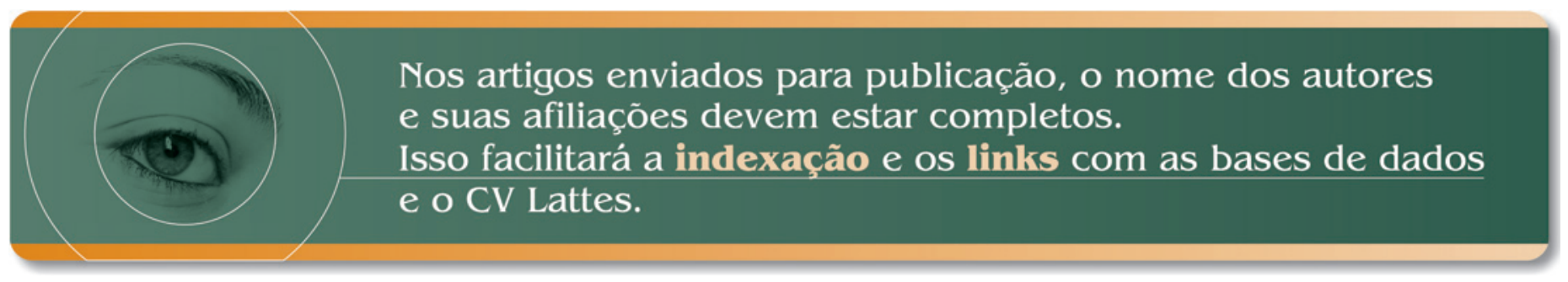

